\title{
Febrile Convulsion among Hospitalized Children Aged Six Months to Five Years and Its Association With Haemoglobin Electrophoretic Pattern
}

\author{
Adeboye $\mathbf{M}^{1}$, Ojuawo $A^{1}$, Adeniyi A ${ }^{1}$, Ibraheem RM${ }^{1}$, Amiwero $C^{2}$
}

ABSTRACT

BACKGROUND: Febrile convulsion and sickle cell disease are common in tropical countries and both are associated with significant morbidity and mortality. Worldwide, Nigeria has the highest prevalence of sickle cell disease. However, there is a dearth of knowledge on the haemoglobin electrophoresis in patients with febrile convulsions.

METHODS: This was a hospital based, descriptive, cross-sectional study of the relationship between haemoglobin genotype and febrile convulsion at the University of Ilorin Teaching Hospital over a period of 12 months. A self-designed pretested questionnaire was administered on the subjects, and necessary examinations and investigations were conducted.

RESULTS: Of a total of 1675 children admitted into the emergency paediatric unit during the study period, children aged 6 months-5 years that presented with febrile convulsions were 167(10\%) . Of this, 1,212 were aged 6 months-5 years. Thus, the age specific, hospital-based prevalence was $13.8 \%$. The M:F was 1.1:1. Their Haemoglobin genotype distribution was $A A$ 131(78.4\%), AS 23(13.8\%), AC 6(3.6\%), SS 6(3.6\%), and 1(0.6\%) SC. The mean age of the

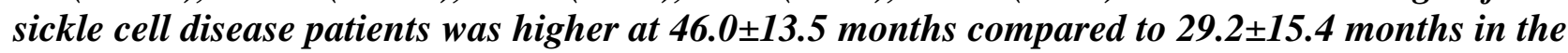
non-sickle cell disease patients $(p=0.005)$. The mean packed cell volume in subjects with sickle cell anaemia was $8.8 \pm 1.5 \%$; the only case of haemoglobin SC had packed cell volume of 20\%, while the non-sickle cell disease patients had a normal PCV. Malaria was present in $80.4 \%$ of them.

CONCLUSION: Febrile convulsion remains a common cause of hospitalisation. It is uncommon in haemoglobin SS where severe anaemia is always an accompanying derangement. The packed cell volume is nearly normal in children with normal haemoglobin genotype.

KEYWORDS: Febrile Convulsion, haemoglobin genotype, children, Malaria

DOI: http://dx.doi.org/10.4314/ejhs.v25i3.8

\section{INTRODUCTION}

Febrile convulsions are convulsions that occur between the ages of 6 months and 5 years during a febrile illness without evidence of intracranial infection or other defined central nervous system causes (1-4). This condition is prevalent worldwide (1-5) largely because of the ubiquitous nature of infections resulting in fever. The incidence varies from country to country and region to region even within the same country $(1-2,5$.) The average incidence worldwide is put at $2-5 \%$. It thus constitutes a significant cause of morbidity in children.(57).

\footnotetext{
${ }^{1}$ Department of Paediatrics, University of Ilorin Teaching Hospital, Ilorin, Kwara State, Nigeria

${ }^{2}$ Department of Haematology, Federal Medical Centre, Bida, Niger State, Nigeria

Corresponding Author: Adeboye MAN, Email: adeboyeman@yahoo.co.uk
} 
Sickle cell disease is a common genetic disorder in the tropics, and it remains a major cause of morbidity and mortality in children (8-13). Its prevalence among Nigerian children is $2-3 \%$ while about $25 \%$ of the population carries the abnormal S-gene.(8-12). Sickle cell disease is associated with various neurologic complications such as meningitis, cerebrovascular accidents, seizures/seizure disorders, regression of already attained milestones and cerebral infarctions.(1415). This group of children have also been found to be prone to infections in comparison with the general populace because of the defects in their general immune status $(8,15-16)$. Such infections may result in fever, a major trigger of convulsions in children.

Malaria has been found to be the commonest infection associated with febrile convulsions in tropical environment as well as a significant precipitant of crises among patients with sickle cell disease. Both febrile convulsion and sickle cell disease are common in tropical countries, and both are associated with significant morbidity and mortality $(14,17)$. Hypothetically, therefore, it can be inferred that incidence of febrile convulsion in sickle cell disease patients would be more than observed in the general population. This study was therefore conducted to affirm the correctness or otherwise of this assertion. Also, it was aimed at determining the hospital based prevalence of febrile convulsion, contribution of malaria to the burden, and the pattern of packed cell volume seen in children presenting with febrile convulsions and how these vary with their haemoglobin genotype.

\section{PATIENTS AND METHODS}

This is a hospital based, descriptive crosssectional study that was conducted over a period of twelve months at the EPU of the University of Ilorin Teaching Hospital-a tertiary institution which serves as referral centre for hospitals and clinics within Kwara State, and adjoining Niger, Oyo, Ekiti, Kogi and Osun States.

All patients admitted in the emergency paediatric unit with a diagnosis of febrile convulsion during the study period were included conveniently. Inclusion criteria include patients aged 6 months -5 years who presented with fever and convulsion (whether the fever was documented or historic) in the current illness. Exclusion criteria include afebrile convulsions, blood transfusion in the previous 120 days if the haemoglobin genotype is not known and Cerebrospinal fluid microbiology and/or biochemical analysis suggesting meningitis.

A total of 167 patients met the inclusion criteria and were admitted and recruited. According to the institutional policy, a child with febrile convulsion is never treated on out-patient basis, but can be discharged after 24 hours if he/she is stable enough, and no signs of complications are observed. Detailed clerkings and thorough physical/clinical examinations were carried out. Investigations found to be necessary based on the child's condition were also done. All the subjects, however, had their blood drawn for full blood count (FBC), malaria parasite, haemoglobin genotype (if not already known) by the research team members. Standard aseptic technique was observed throughout the procedure.

The FBC was carried out by automated KX $21 \mathrm{~N}$ sysmex cell counter; thick blood film for malaria parasite was employed for the determination and parasite load of malaria parasite, while cellulose acetate method of $\mathrm{Hb}$ electrophoresis was used to determine the haemoglobin type. These were conducted by the laboratory technicians with supervision from consultant haematologist to ensure quality control. Thick film of malarial parasite was done on a glass slide using the standard method.

Reporting the Thick Film: A drop of immersion oil was applied to the film which was viewed under microscope using the 100x objective to examine at least 100 high power fields(HPF).

The findings of :

1-10 parasites per 100HPF was recorded as + 11-100 parasites per 100HPF as ++

1-10 parasites in one HPF as +++

more than 10 parasites in one HPF as ++++.

The study was approved by the Ethical Review Committee of the UITH. Information was gathered with a pre-tested self-designed questionnaire. Data entry was made into microcomputer and analysis was done with the use of Epi-Info Software Package (version 6.04 of 2001). Chi-square test and student $t$-test were used to test for statistical significance of the difference for discreet and continuous variables respectively. A $p$-value of less than or equal 0.05 was regarded as significant. 


\section{RESULTS}

The total number of patients admitted into the Emergency Paediatric Unit ( EPU ) over the study period was 1,675 . Their ages ranged from 1 day to 18 years ( Table 1 ). Those whose ages ranged from 6 months to 5 years were 1,212 constituting $72.4 \%$ of the total admissions. In all, there were 935 males and 740 females giving a male to female ratio of 1.3:1. One hundred and sixty seven of the children aged 6 months to 5 years presented with febrile convulsions, thus constituting $10.0 \%$ of the total admissions, and $13.8 \%$ of those aged 6 months to 5 years. This gives an age-specific hospital based prevalence of febrile convulsion of $13.8 \%$. There were $104(11.1 \%)$ males and 80(10.8) females whose ages were within the first four weeks of life in the overall admission. The mean age in the SCD children of $46 \pm 13.5$ months was significantly higher compared to $29.2 \pm 15.4$ months recorded in the non-SCD ( $p=0.0049)$ (Table 2).

Table 1: Age and sex distribution of all admissions over the study period.

\begin{tabular}{lcccc}
\hline Age & $\begin{array}{c}\text { Male (\%) } \\
\mathbf{n = 9 3 5}\end{array}$ & $\begin{array}{c}\text { Female (\%) } \\
\mathbf{n = 7 4 0}\end{array}$ & $\begin{array}{c}\text { Total (\%) } \\
\mathbf{N = 1 6 7 5}\end{array}$ & $\boldsymbol{p}$ \\
\hline$<28$ days & $104(11.1)$ & $80(10.8)$ & $184(11.0)$ & 0.840 \\
1-12mth & $289(30.9)$ & $190(25.7)$ & $479(28.6)$ & 0.019 \\
13-36mth & $223(23.9)$ & $164(22.2)$ & $387(23.1)$ & 0.416 \\
37-60mth & $185(19.8)$ & $178(24.1)$ & $363(21.1)$ & 0.035 \\
6-12yrs & $81(8.7)$ & $187(25.3)$ & $168(10.0)$ & $<0.001$ \\
12+years & $53(5.7)$ & $41(5.5)$ & $94(5.6)$ & 0.910 \\
Total & $\mathbf{9 3 5}(\mathbf{1 0 0})$ & $\mathbf{7 4 0}(\mathbf{1 0 0})$ & $\mathbf{1 6 7 5}(\mathbf{1 0 0})$ & \\
\hline
\end{tabular}

Table 2: Age and sex distribution of children with febrile convulsions cdmitted during the study period.

\begin{tabular}{lllll}
\hline Age (Months) & $\begin{array}{l}\text { Male (\%) } \\
\mathbf{n = 8 9}\end{array}$ & $\begin{array}{l}\text { Female (\%) } \\
\mathbf{n = 7 8}\end{array}$ & $\begin{array}{l}\text { Total (\%) } \\
\mathbf{N = 1 6 7}\end{array}$ & $\boldsymbol{P}$ \\
\hline 6-12 (Infant) & $13(14.6)$ & $11(14.1)$ & $24(14.4)$ & 0.93 \\
13-36 (Toddler) & $52(58.4)$ & $49(62.8)$ & $101(60.5)$ & 0.56 \\
37-60 (Pre-school) & $24(27.0)$ & $18(23.1)$ & $42(25.1)$ & 0.56 \\
Mean age & $29.9 \pm 15.5$ & $29.9 \pm 14.8$ & $29.9 \pm 15.1$ & \\
\hline
\end{tabular}

Haemoglobin Genotype of the Study Population: Of the 167 children managed for febrile convulsions, 131(78.4\%) children had haemoglobin genotype AA, 23(13.8\%) AS, $6(3.6 \%) \mathrm{AC}$, another $6(3.6 \%) \mathrm{SS}$ and $1(0.6 \%)$ SC. A comparison for the occurrence of febrile convulsion between the haemoglobin genotype AA (131/160) and the children with sickle cell anaemia (HbSS) (1/7) showed a statistically significant difference (Yate's $\chi^{2}=14.05$, Yate's corrected $p<0.05)$ (Table 3).

Table 3 :Haemoglobin genotype distribution by age among children with febrile convulsions.

\begin{tabular}{llllllll}
\hline $\begin{array}{l}\text { Age group } \\
\mathrm{N}=167\end{array}$ & $\begin{array}{l}\mathrm{AA} \\
\mathrm{n}=131\end{array}$ & $\begin{array}{l}\mathrm{AS} \\
\mathrm{n}=23\end{array}$ & $\begin{array}{l}\mathrm{AC} \\
\mathrm{n}=6\end{array}$ & $\begin{array}{l}\text { Subtotal (\%) } \\
\text { Non SCD } \\
\mathrm{n}=160\end{array}$ & $\begin{array}{l}\mathrm{SS} \\
\mathrm{n}=6\end{array}$ & $\begin{array}{l}\mathrm{SC} \\
\mathrm{n}=1\end{array}$ & $\begin{array}{l}\text { Subtotal (\%) } \\
\text { SCD } \\
\mathrm{n}=7\end{array}$ \\
\hline Infancy 24 & 18 & 5 & 1 & $24(15.0)$ & 0 & 0 & $0(0)$ \\
Toddler 101 & 82 & 14 & 3 & $99(61.9)$ & 2 & 0 & $2(28.6)$ \\
Pre-school 42 & 31 & 4 & 2 & $37(23.1)$ & 4 & 1 & $5(71.4)$ \\
Total & 131 & 23 & 6 & $160(100)$ & 6 & 1 & $7(100)$ \\
\hline AA Versus $S S$ & \multicolumn{7}{c}{ (Yate's $\chi^{2}=14.05$, Yate's corrected $p<0.05$}
\end{tabular}


Distribution of Packed Cell Volume According to Patient's Haemoglobin Genotypes: All the six children with haemoglobin genotype SS (100\%) presented with PCV of less than $15 \%$ and with a mean PCV of $8.8 \pm 1.5 \%$. The only child with haemoglobin genotype SC presented with PCV of $20 \%$. Of the 123 children whose PCV ranged between 16-29\%, 97(78.9\%) had AA, 5( 4.1\%) had AC, $20(16.3 \%)$ had AS and only $1(0.8 \%)$ was SC. The PCV recorded in the other children is as shown in Table 4. The mean PCV of the children with haemoglobin genotype AA was $28 \pm$ $3.2 \%$, while that of $\mathrm{AS}+\mathrm{AC}$ was $27.3 \pm 2.3 \%$. Using Kruskal-Wallis one way analysis of variance, (Kruskal-Wallis $\mathrm{H}=23.36, p=0.001$ ) which was statistically significant (Table 4 ).

Table 4: Packed cell volume categories versus haemoglobin genotype.

\begin{tabular}{|c|c|c|c|c|c|c|c|}
\hline \multirow[b]{2}{*}{$\begin{array}{l}\text { Packed Cell } \\
\text { Volume }\end{array}$} & \multirow[b]{2}{*}{$\begin{array}{l}\mathrm{AA} \\
\mathrm{n}=131\end{array}$} & \multicolumn{6}{|c|}{ Haemoglobin Genotype } \\
\hline & & $\begin{array}{l}\text { AS } \\
n=23\end{array}$ & $\begin{array}{l}\mathrm{AC} \\
\mathrm{n}=6\end{array}$ & $\begin{array}{l}\text { Subtotal }(\%) \\
\text { Non SCD } \\
\mathrm{N}=160\end{array}$ & $\begin{array}{l}\mathrm{SS} \\
\mathrm{n}=6\end{array}$ & $\begin{array}{l}\mathrm{SC} \\
\mathrm{n}=1\end{array}$ & $\begin{array}{l}\text { Subtotal (\%) } \\
\text { SCD } \\
\mathrm{N}=7\end{array}$ \\
\hline $7-15$ & - & - & - & - & 6 & - & $6(85.7)$ \\
\hline $16-29$ & $97(74.0)$ & 20 & 5 & $25(86.2)$ & - & 1 & $1(14.3)$ \\
\hline 30 and above & $34(26.0)$ & 3 & 1 & $4(13.8)$ & - & - & $0(0.0)$ \\
\hline
\end{tabular}

SCD Versus Non-SCD : One way ANOVA: Kruskal-Wallis $\mathrm{H}=23.36, \quad \mathrm{df}=4, \quad p=0.001$

Distribution of Malaria Parasitaemia in Accordance with Haemoglobin Genotype: Across all the identified haemoglobin genotypes in the children with febrile convulsions, 32(19.2\%) children had no malaria parasitaemia of which 27(84.4\%) were AA, and 5(15.6\%) were AS. A total of $135(80.5 \%)$ children had malaria parasitaemia of varying degrees. Haemoglobin genotype AA was 104(77.0\%), AC+AS genotype was 24 (17.8\%), and SC+SS constituted 5.2\% (being positive in all the 7 children in this category). The severity of malaria parasitaemia was analyzed across the haemoglobin genotype. Fourteen $(53.8 \%)$ of the AC+AS group had the least malaria parasite load $(+)$ in contrast to haemoglobin $\mathrm{AA}(15.4 \%)$ and $\mathrm{SC}+\mathrm{SS}(14.3 \%)$ as shown in Table 5. However, this observation wasnot statistically significant $(p>0.05)$.

Table 5: Malaria parasitaemia according to haemoglobin genotype

\begin{tabular}{llllll}
\hline \multirow{2}{*}{ Malaria parasite load } & \multicolumn{5}{l}{ Haemoglobin Genotype } \\
& $\begin{array}{l}\text { AA } \\
\mathrm{n}=131\end{array}$ & $\begin{array}{l}\mathrm{AS}+\mathrm{AC} \\
\mathrm{n}=29\end{array}$ & $\begin{array}{l}\text { Subtotal } \\
\text { Non SCD } \\
\mathrm{N}=160(\%)\end{array}$ & $\begin{array}{l}\text { SCD } \\
\text { SS + SC } \\
\mathrm{N}=7(\%)\end{array}$ & $p$ \\
\hline No malaria parasite & 27 & 5 & $32(20.0)$ & - & \\
1-10 parasite / 100HPF $(+)$ & 16 & 14 & $30(18.8)$ & $1(14.3)$ & 0.77 \\
$11-100$ parasite / $100 \mathrm{HPF}(++)$ & 66 & 10 & $76(47.5)$ & $5(71.4)$ & 0.12 \\
$\geq 1-10$ parasite / HPF $(\geq+++)$ & 22 & 0 & $22(13.8)$ & $1(14.3)$ & 0.96 \\
\hline
\end{tabular}

\section{DISCUSSION}

This study has demonstrated that $\mathrm{FC}$ remains one of the common causes of hospital admissions among under-fives with an age-specific prevalence rate of $13.8 \%$. It also represented about $10.0 \%$ of total admissions into the emergency room. An earlier study from this center (Ilorin) (5) reported a prevalence of $11.5 \%$ although it was not age-specific. Prevalence rates quoted nationwide vary between $8.1-15.6 \%(5,18-21)$. Thus, it can be inferred that the prevalence is still high.

Febrile convulsion was found to be commoner in males. A similar finding has been described by several authors both locally and 
internationally (4-5,22-23). This, however, contrasts with the findings from a rural community-based study on febrile convulsions in Afon, a rural community in Kwara state which showed a female preponderance (24). Environmental, methodological as well as demographic characteristics of the community might have been responsible for this observation though many of the studies that showed male preponderance were hospital based $(4-5,21)$. The mean age was found to be $29.9 \pm 15.1$ months with very little variation in either sex as previously reported $(5,21)$. The toddler age-group (13-36 months) were mostly affected and this probably reflects their susceptibility to infections (25-26).

Children with haemoglobin genotype AA constituted the majority of the study population. This could be a reflection of the normal distribution of the haemoglobin genotype within the population (27). In addition, it may probably be due to the fact that children with haemoglobin genotype AA are more prone to malaria (28) due to lack of the S-gene which when present in the heterozygous carrier (AS) state protects against attacks of malaria $(15,28-29)$ in keeping with the concept of balanced polymorphism (28). Also, parasitized erythrocytes with abnormal haemoglobin-S are rapidly cleared from the circulation hence limiting the effect of parasites on the body $(16,28)$.

The mean age at which febrile convulsions occurred overall in this study was $29.9 \pm 15.1$ months which is in consonance with some earlier studies $(5,21)$ that reported 30 months but at variance with mean age of 18.9 months reported by Lewis et al (30) in British children. In the sickle cell disease patients, however, the mean age was found to be $46.0 \pm 13.5$ months as compared to $29.2 \pm 15.4$ months in the non-sickle cell disease patents. However, the explanations for this is not clear.

The PCV of children studied ranged from 7 $38 \%$ with an overall mean of $27.2 \pm 4.7 \%$. Six of the seven children with SCD had PCV of less than $15 \%$ which categorized them in the ambit of severe anaemia by WHO standard (28). The nonSCD, on the other hand, had a mean PCV of 27.7 $\pm 2.8 \%$ which is just marginally lower than the lower limit of the normal. Strictly speaking, the children with SCD that had PCV low enough to cause a convulsion could have been excluded, but if this had been done, the only subject that would have been recruited in that group would have been the subject with haemoglobin SC who had a PCV of $20 \%$. Some experienced clinicians have opined that febrile convulsion is rare in children with sickle cell anaemia (31).

Malaria parasitaemia load was least in children with haemoglobin genotype AS+AC; the majority of them had 1-10 parasites per 100 high power field $(+)$, and none of them had a parasitaemia load of three pluses. This is in consonance with the general observation of heterozygous AS being protective against malaria (29). Malaria parasitaemia was found in most cases of febrile convulsions in this study. This is similar to the findings in several other studies $(5,18,20-21)$. All the SCD group had malaria parasitaemia which may be due to their susceptibility to infection in general.

In conclusion, febrile convulsions remain a common cause of hospital admission into the children emergency room in UITH, Ilorin representing $10.0 \%$ of total admission, and hospital based age specific prevalence of $13.8 \%$. Its occurrence is uncommon in patients with haemoglobin genotype SS where severe anaemia is always an accompanying derangement. PCV is normal in most cases of children with normal haemoglobin genotype. Malaria parasitaemia was found in most cases of febrile convulsions.

Non-inclusion of severe anaemia as an exclusion criteria is the limitation of this study as severe anaemia on its own can cause convulsions as a result of cerebral hypoxaemia (32-33). However, if this was done, only one SCD patient (haemoglobin genotype SC) would have merited being included in the study. It is hereby suggested that studies should be conducted to determine the contribution of features such as severe anaemia and cerebrovascular accidents in causation of convulsions in a febrile SCD child with convulsion.

\section{REFERENCES}

1. Ouellette EM. Febrile Convulsions. In:

2. Dersherwitz RA ed. Ambulatory Pediatric Care. Lippincott-Raven, New York:1993; 578-80.

3. Fetveit A. Assessment of febrile seizures in children. Eur J Pediatr. 2008;167:17-27.

4. Iloeje SO. The impact of socio-cultural factors on febrile convulsion in Nigeria, West Afr J Med 
1989; 8: 54-8.

5. Shinnar S, Glauser TA. Febrile seizures. J Child Neurol 2002; 17 Suppl 1: S44-52.

6. Fagbule D, Chike-Obi UD, Akintunde EA. Febrile convulsions in Ilorin. Nig J Paediatr 1991; 18: 23

7. Rutter N, Smales ORC. Role of routine investigations in children presenting with their first febrile convulsion. Arch Dis Child 1977; 52: 18191.

8. Berg TA, Shinnar S, Hauser WA, Leventhal JM. Predictors of recurrent febrile seizures: A metaanalytic review. J Pediatr 1990; 116: 329-36.

9. Olanrewaju DM. Complications of sickle cell anaemia - A review. Nig Med Pract 1988; 16: 10711.

10. Oyedeji GA. Knowledge and perception of sickle cell disorders in parents of affected children. Nig Med Pract 1990; 19: 34-7.

11. Omotade OO, Kayode CM, Falade SL, Ikpeme S, Adeyemo AA, Akinkugbe FM. Routine screening for sickle cell haemoglobinopathy by electrophoresis in an infant welfare clinic. West Afr J Med 1998; 17: 91-4.

12. Kaine WN. Morbidities of homozygous sickle cell anaemia in Nigerian children. J Trop Pediatr 1983; 29: 104-10.

13. Kjeldsen MJ, Corey LA, Solaas MH, Friis ML, Harris JR, et al. (2005) Genetic factors in seizures: a population-based study of 47,626 US, Norwegian and Danish twin pairs. Twin Res Hum Genet 8: 138-147.

14. Maharajan R, Fleming AF, Egler LJ. Pattern of infections among patients with sickle cell anaemia requiring hospital admission. Nig J Paediatr 1983; 10: 13-7.

15. Adeloye A, Odeku EL. The nervous system in sickle cell disease. Afr J Med Sci 1970; 1: 33-48.

16. Sodeinde O, Ambe JP, Fatunde OJ. Mixed anaemic crises in patients with sickle cell anaemia. Nig $J$ Paediatr 1999; 26: 30-3.

17. Adedeji MO. The body defences against infection in sickle cell anaemia. Nig Med Pract 1989;17:99.

18. Elderdery AY, Mohamed BA, CooperAJ , Knight $G$ and Mills J. Tribal distribution of haemoglobinopathies in a Sudanese patient population. J. Med. Lab. Diagn 2011; 2(4): 31-37 Available online http://www.academicjournals.org/JMLD.

19. Familusi JB, Sinnette $\mathrm{CH}$. Febrile convulsions in Ibadan children. Afr J Med Sci 1971; 2: 135-49.
20. Izuora GI, Azubuike JC. Prevalence of seizure disorders in Nigerian children around Enugu. Central Afr J Med 1977; 23: 80-3.

21. Ighogboja IS, Angyo I, Okolo AA, Szlachetka R. Morbidity and mortality patterns of paediatric emergencies in Jos, Nigeria. Nig Med Pract 1995; 30: $15-8$.

22. Angyo IA, Lawson JO, Okpeh ES. Febrile convulsions in Jos. Nig J Paediatr 1997; 24: 7-13.

23. Waruiru C, Appleton R. Febrile seizures: an update. Arch Dis Child 2004; 89: 751-756.

24. Hirtz DG, Nelson KB. The natural history of febrile seizures. Pediatr Clin North Am 1989; 36: 365-82.

25. Joiner KT, Obajimoh JA. Febrile convulsions in children at Afon community (abstract). Nig J Paediatr 1986; 13:100.

26. Syndi Seinfeld DO, Pellock JM. Recent Research on Febrile Seizures: A Review. J Neurol Neurophysiol 2013;4: 165. doi:10.4172/21559562.1000165.

27. Livingston JH. Febrile Convulsions. In: Campbell AGM, McIntosh N eds. Forfar and Arneil's Textbook of Paediatrics. Churchill Livingstone, New York: 1992: 754-5.

28. Adewuyi JO, Akintade EA. Survey of haemoglobin genotytpe in children at Ilorin. Nig $J$ paediatr 1990;17: 23-6.

29. WHO Guidelines for the Treatment of Malaria. Treatment of Severe Malaria 2006; 41-54.

30. Armon K, Stephenson T, MacFaul R, Hemingway P, Werneke U, Smith S. Childhood Seizure guideline - An evidence and consensus based guideline for the management of a child after a seizure. Emerg Med J 2003;20:13-20.

31. Lewis HM, Parry JV, Parry PR. Role of Viruses in febrile convulsions. Arch Dis Child 1979; 54: 869.

32. Adedoyin OT, Adesiyun OO, Adeboye MA, Mark F. Hypothetical Views On Some Unusual Disease Associations With Sickle Cell Anaemia. Trop J Health Sci 2010; 17 (1) 8-11.

33. Huck JG. Sickle cell anaemia. Bull Johns Hopkins 1923: 34: 335-44.

34. Sergent GR. The Natural History of Sickle Cell Disease. Cold Spring Harb Perspect Med 2013;3:a011783 ; doi: 10.1101/cshperspect.a011783. 